\title{
UNDERSTANDING AIRLINE BRAND EQUITY DRIVERS: LESSONS FROM A MULTIPLE CASE STUDY
}

Kallol Das

MICA, Ahmedabad, India

Karman Khanna

MICA, Ahmedabad, India

Surankita Ganguly

GCMMF, Anand, India

\begin{abstract}
There is increasing consumer involvement and hence, investor interest in the airlines industry, as far as emerging economies is concerned. A study of the literature by the authors did not produce any research paper on the process drivers of brand equity in the context of airlines. Therefore, the present study makes an attempt to address this gap. The primary research question is: What are the driving factors for building brand equity in the case of airline services? This paper uses a "two-case" multiple-case design employing theoretical replication. The cases are based on two Indian organizations, Indigo Airlines and Go Air. Both these businesses are similar in many aspects but have achieved very contrasting outcomes. The primary research question is broken down into following two secondary research questions. How is Indigo Airlines building its brand? How is Go Air building its brand? Data collection involved use of documents, archives, observations, participant-observations, and surveys. Data analysis involved conducting cross-case analysis. The findings have been used to develop a conceptual framework for building brand equity in airlines.
\end{abstract}

Keywords: Branding, Airlines, Services, Brand Equity, India, Case Study Research

Assoc. Prof. Dr Kallol Das: MICA, Ahmedabad, India; Email: kallol@micamail.in ; getkdas@gmail.com (Corresponding Author)

Karman Khanna: MICA, Ahmedabad, India; Email: karman fpm15@micamail.in

Surankita Ganguly: GCMMF, Anand, India; Email: surankita14@micamail.in 


\section{INTRODUCTION}

The commercial importance of services has been growing constantly over the years. Further, branding has been discussed as "the cornerstone of services marketing for the twenty-first century" (Berry, 2000, p. 129). Consequently, research aimed towards studying the branding of services has also gained impetus; and the question of whether services should follow the same principles of brand building as manufactured goods has been raised time and again (Szmigin \& O'Loughlin, 2007). Considered as one of the most intangible service sectors, the aviation industry contributes considerably to the global economy (Kee Mun \& Ghazali, 2011). This paper attempts to understand the intricacies of airline branding, in the specific context of an emerging economy like India.

\section{LITERATURE REVIEW}

In this section, scholarly literature pertaining to studies on branding, brand equity, and branding in airlines domain is reviewed. They are presented in the following sub-sections.

\subsection{Branding}

As per American Marketing Association (AMA), a brand can be defined as a "name, term, sign, symbol, or design, or a combination of them, intended to identify the goods or services of one seller or group of sellers and to differentiate them from those of competition" (Keller, 1993, p. 3). According to Charlene (2007), the concept of branding is considered to be most vital for marketing. Branding contributes to building a base of loyal customers motivated to purchase the same goods and services (Dibb \& Simkin, 1993). Moorthi (2002) discusses the steps for effective branding. According to Xiang and Petrick (2008), the primary objective of branding is to build an attractive image in the minds of the consumers which is an antecedent for gaining his or her trust and loyalty.

Due to the unique characteristics of services (i.e., intangibility, heterogeneity, inseparability, perishability), branding has been found to be more useful to services than goods (de Charnatony \& McDonald, 1998; Kapferer, 2004). A strong service brand helps in visualizing the invisible product and increases consumer trust (Berry, 2000) by reducing perceived risk (Chang, Hsu, \& Chung, 2008). Furthermore, Cobb-Walgren, Ruble, \& Donthu (1995) and Chen \& Chang (2008), found that a service brand with higher brand equity produced significantly higher brand preference and purchase intention. Interestingly, Vargo \& Lusch (2004a; 2004b) 
discussed how the principles of services are equally applicable to goods. Therefore, the concepts of service branding should also be useful to marketers of physical goods. Even, Berry (2000, p. 130) mentioned that his proposed service brand equity model "differs in degree, not kind, from a packaged-goods branding model."

\subsection{Brand Equity}

Brand equity, defined simply, is the value addition (or value destruction) that a brand provides to an, otherwise, unnamed or fictitiously named version of the product or service (Charlene, 2007). According to Keller (1993, p. 60), customer-based brand equity (as opposed to financial-based brand equity) is defined as "the differential effect that brand awareness and brand meaning combined has on consumer response to the marketing of that brand."

There are several well accepted brand equity frameworks (e.g., Aaker, 1991; Keller, 1998). However, the brand equity framework proposed by Berry (2000) stands out since it singularly focuses on the service sector. Further, this model was empirically validated by Fung So and King (2010).

Figure 1: Service branding model (Berry, 2000)

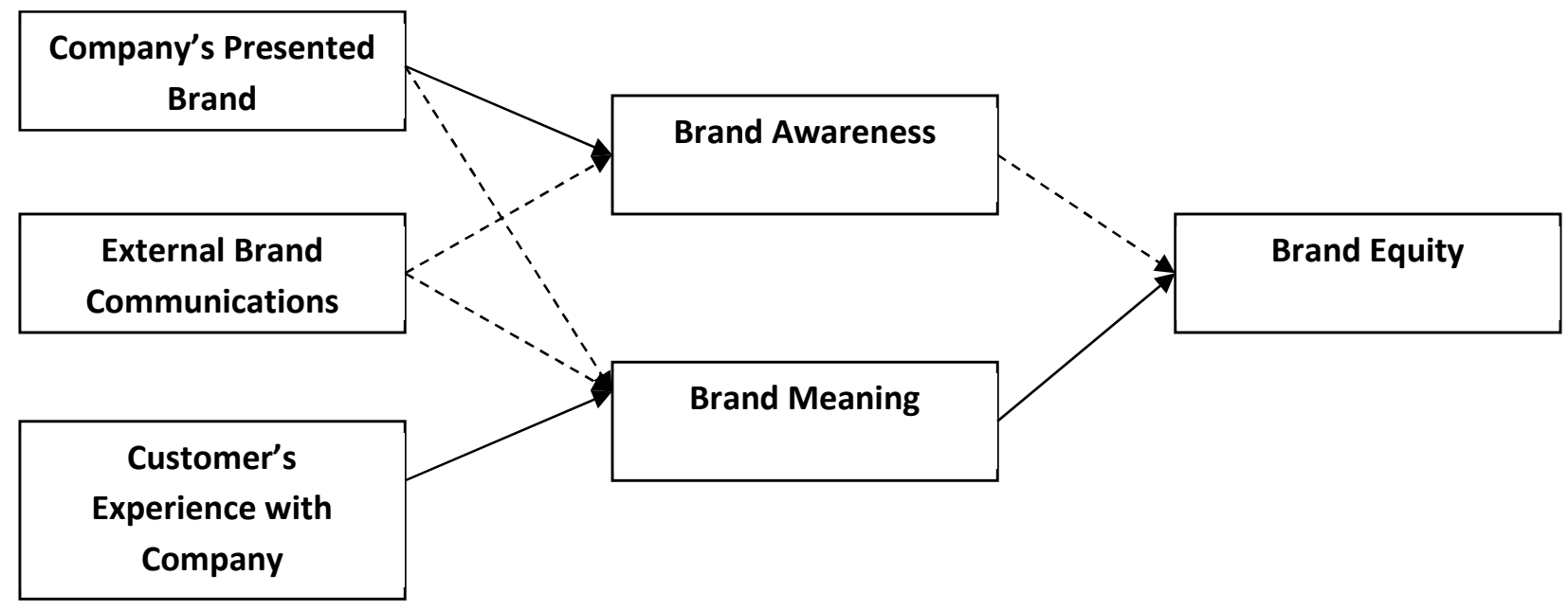

The bold lines in the model, depicted in figure 1, indicate an impact which is direct and primary whereas the dotted lines indicate a secondary impact. There are three key components viz. 'presented brand', 'external brand communications', and 'customer's experience with company'. According to Berry (2000), these three components contribute, directly or indirectly, to brand awareness and brand meaning, which combined together constitute brand knowledge as per Keller (1993). 
The company's presented brand as defined by Berry is the company's controlled communications such as advertising, packaging, and so on. External brand communications refer to the uncontrolled understanding that the customers derive about the organization. It can be through word of mouth which is increasingly becoming an independent source of seeking opinions or through publicity which is not in the full control of the organization. Customer experience as stated above is the firsthand encounter of the customer with the brand and its services. Brand awareness is the familiarity of the customers with the brand and brand meaning refers to the dominant perception about the company that the customer holds at top of the mind. Brand equity is the knowledge of the brand that resides in the minds of consumers. Berry basically suggests that customer's experience with the company is a dominant contributor to brand meaning, which is a dominant contributor to brand equity.

Further, a study by Bick (2009) suggests that there is a positive relationship between brand equity and shareholder value. In fact, brands can account upto $25 \%$ of a company's market value (Bick, 2009). According to another study, brand equity can lead to brand profitability and brand sales volume (Baldauf \& Cravens, 2003). Another study suggests that brand equity has a positive impact on customer acquisition, retention, and profitability (Stahl, Heitmann, Lehmann, \& Neslin, 2012). Also, Kim, Kim, \& An (2003) found, in the context of hotel sector, that a high brand equity can lead to significant increase in revenues.

\subsection{Branding Studies of Airlines}

Kee Mun and Ghazalo (2011) identified seven dimensions of brand satisfaction in their study of two Malaysian airlines: tangibles, price, core services, reputation, publicity, word of mouth, and employees. A study of brand equity in the case of airlines done by Chen \& Tseng in Taiwan (2010) operationalized airline brand equity with four dimension: brand awareness, brand image, perceived quality and brand loyalty. However, the authors did not get any research paper on the process drivers of brand equity in the context of airlines. Given that there is increasing consumer involvement and hence, investor interest in this industry, an understanding of the process drivers of brand equity is essential. Therefore, the present study aims to address this gap.

Also, there is a boom in India so far as air travel is concerned - thanks to low air fares and the recently implemented seventh pay commission and investor-friendly policies (Kulshrestha \& Chaturvedi, 2016). As a result, most of the airline brands in India are presently on an expansion spree (Chowdhury, 2016). These airlines will stand to gain by a study that focuses on understanding brand equity drivers of airline services. The present study is also expected 
to benefit airlines in other emerging economies in their pursuit of high brand equity development and consequent higher market shares.

\section{RESEARCH METHODOLOGY}

The following is the research question for the present study based on the gap identified in literature: What are the driving factors for building brand equity in the context of airline services?

The present paper uses case study research method, which is an empirical enquiry to address "how" or "why/ what" questions about any contemporary phenomenon over which the investigator has little or no control (Yin, 2009). The choice of case study research design was made on two grounds: its ability to adequately address the chosen research question as well as the authors' expertise in using this research design.

In designing the present case research, a multiple case-design was chosen as it is considered as being more robust (Herriott \& Firestone, 1983). A multiple case study is analogous to multiple experiments, where the primary logic is replication (Rowley, 2002). According to Yin (2009), in multiple case designs, the cases can be selected in such a way that they either (a) predict similar results (termed literal replication) or (b) predict contrasting results that are explainable (termed theoretical replication). If the results from the multiple cases turn out as predicted, either literally or theoretically, then the findings become more compelling (Rowley, 2002). In situations where resources are scarce (as in the case of the present research), a theoretical replication-based study is far superior to one using literal replication (Yin, 2009). Therefore, it was decided to have a "two-case" multiple-case design employing theoretical replication.

\subsection{Case Selection}

In order to achieve theoretical replication, two Indian airlines were chosen as case organizations. Both these firms, Indigo Airlines and Go Air, are similar in many aspects but have achieved very contrasting outcomes. Both are budget airlines that started at around the same time (i.e., 2004-05) and use Airbus aircrafts. Even their names are similar. However, Indigo Airlines is the leader in the Indian market with a share of $38 \%$ in $2015-16$ (Ghosh, 2016). On the other hand, Go Air is a laggard operating at a market share of $8.1 \%$ (Shukla, 2016). The broad, primary research question was broken down into the following two secondary research questions. 
1. How is Indigo Airlines building its brand?

2. How is Go Air building its brand?

By studying these contrasting cases, the authors aim to distill the key principles of effective branding with respect to airline services. The design discussed above is depicted graphically as follows:

Figure 2: Case study research design
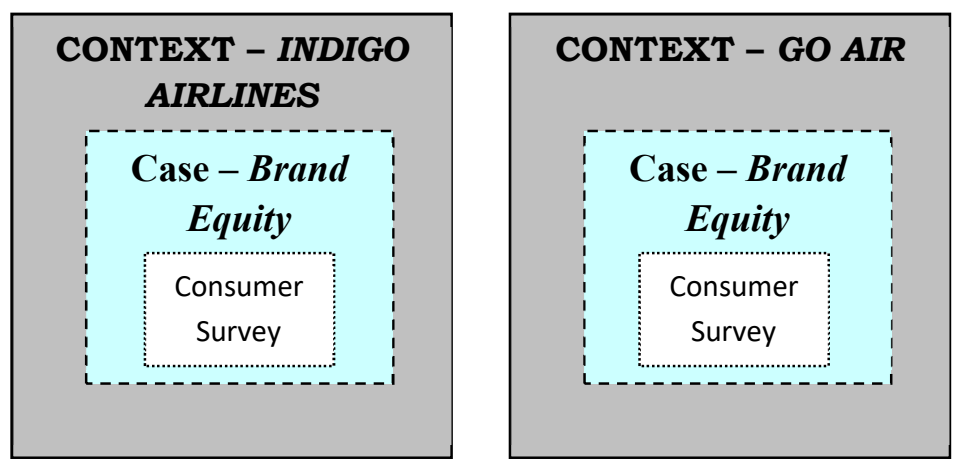

Data collection was done using a variety of sources such as documents (both internal as well as public), archives (from the website of the directorate general of civil aviation), observations and participant-observations by the authors.

Further, cross-case synthesis technique was used to analyze the case data. According to Yin (2009), this technique is most suitable for multiple case studies.

For the embedded consumer surveys, data was collected from Generation $Y$ consumers from different parts of the country. Gen $Y$ individuals are ones born between 1980 and 2000 (Cennamo \& Gardner, 2008); (Weingarten, 2009). Further, for most businesses, they represent future profitable customers as their lifetime values are high (de Torcy, Taylor, Delhaye, Schickel, \& Fulcher, 2005). Hence, they were chosen as respondents for the study. For doing the survey, a sample of 480 Gen $Y$ consumers was recruited. Out of this, only 390 participants completed the survey. Sampling was done using convenience method, with the implication that results cannot be generalized beyond the sample. The survey was administered online using Google Forms.

\section{DATA ANALYSIS}

The effectiveness of brand building efforts will be measured using two parameters: a) present market share, and b) consumer evaluations. Case selection has been based on market share 
as mentioned earlier. This is justified based on the literature review, which suggests that high brand equity can lead to high consumer preferences, thereby leading to high market share.

Berry's service brand equity framework, given its strong service sector emphasis, will be used as the basis for understanding brand building efforts of the case organizations. According to Berry, the broad drivers of service brand equity are: (i) company's presented brand, (ii) external brand communications, and (iii) customer's experience with company.

Further, for understanding company's presented brand, the following three constituents have been identified: brand elements, brand positioning, and advertising. This delineation is based on studies by Keller (1993), Lovelock and Wirtz (2007), and Berry (2000).

According to Keller (1998), brand elements drive brand equity and they could be brand names, logos, characters, slogans, jingles, packages, URLs, and signages. For the present study, the authors have zeroed in on three major brand elements viz. brand name, logo, and slogan. In the present era of smart phone applications, the importance of URLS is declining. Further, none of the chosen airlines have deployed characters and jingles, and hence not applicable. Both airlines use aircrafts made by Airbus Industrie, France and have their logo colours painted all over. Therefore, there was no felt need to assess aircraft packaging separately.

For understanding external brand communications which are not fully in the control of an organization, the following parameters were used: (i) corporate awards, (ii) CSR activities, and (iii) social media activities. This identification is based on work by Lovelock and Wirtz (2007).

Finally, for examining customer's experience with the brand, (i) employee care, (ii) operations design, and (iii) brand promise delivery were the parameters. This selection is based on work done by Lovelock and Wirtz (2007) who argue that an integration of the three functions is essential to meet the needs of service consumers.

In qualitatively analyzing the brand building efforts of the case organizations, two marketing experts were approached. One was services marketing academic and another services marketing practitioner with average work experience of 20 years. They were asked to do cross-case analysis of the data collected by the authors.

Further, consumer evaluation of service quality was done using service performance (SERVPERF) scale (Parasuraman, Zeithaml, \& Berry, 1988). Also, Net Promoter Score (NPS) 
of both the brands was computed. NPS is widely regarded as a reliable indicator of repeat patronage (Reichheld, 2003).

\subsection{Cross-case Analysis}

Here, we present the findings of cross-case analysis using the approach discussed above.

\subsubsection{Company's Presented Brand}

As discussed earlier, this comprised three components viz. brand elements, brand positioning, and advertising. They are further discussed in the following sub-sections.

\subsubsection{Brand Elements}

The brand elements were examined on memorability, meaningfulness, likeability, transferability, adaptability, and protectibility as suggested by Keller (1998). The marketing experts rated the brand elements deployed by both the airlines as "Good". They found the brand elements, in both the cases, a little weak on likeability and transferability, but wellplaced on all other fronts.

Table 1: Cross-case analysis of brand elements of case organizations

\begin{tabular}{|c|c|c|}
\hline Brand Element & Indigo Airlines & Go Air \\
\hline Brand Name & Indigo Airlines & Go Air \\
\hline Logo & $\ldots-\cdots$ & FLY SMART \\
& IndiGo & Fly Smart \\
\hline Slogan & Go Indigo & . \\
\hline
\end{tabular}

\subsubsection{Brand Positioning}

The brand message mentioned by IndiGo Airlines on their website is "low fares, on-time flights and a hassle-free experience" (Indigo, 2016a, p. 3). It is primarily low-cost and on-time. However, that of Go Air states "punctuality, affordability, and convenience" (GoAir, 2016, p. 4). Both these promises are very similar to each other. Go Air further mentions it's positioning as 'the Smart People's Airline'. The tagline 'Fly Smart' reinforces this positioning.

The brand positioning of both the airlines was examined on the parameters of uniqueness and significance as suggested by Ries and Trout (2001). The brand positioning used by both the 
airlines was not found to be very unique and significant, given the similarity in the positioning messages. Therefore, the experts rated the brand positioning of both the airlines as "Good".

Table 2: Cross-case analysis of brand positioning of case organizations

\section{Brand Positioning}

\begin{tabular}{|c|c|}
\hline Indigo Airlines & Go Air \\
\hline Low-Cost/ On-time & Low-Cost/ Smart People's Airline \\
\hline
\end{tabular}

\subsubsection{Advertising}

In the last three years, both IndiGo Airlines (hereinafter referred to as IndiGo) and Go Air (hereinafter referred to as Go) have advertised regularly using the outdoor medium. Outdoor has been the most preferred medium for advertising with Go having a campaign in 2014 for a span of three months (Cardozo, 2014; Chhabra, 2014) and IndiGo having a campaign in 2015 (Kotoky, 2015).

With the tagline 'Ready for take-off', IndiGo at the time of its launch, concentrated on creating a presence through print and outdoor. It started advertising using the radio in the second quarter of 2014 (afaqs, 2015). Based out of Montreal, Tony Tyler, the director general of the International Air Transport Association (IATA) has quoted about IndiGo that "They are very good at marketing themselves" (Kotoky, 2015). This comes at a time when IndiGo is not a member of the IATA. Keeping up with the times, IndiGo also launched a selfie contest for engaging its young audience on Valentine's Day in 2015 (Neogy, 2015). Go has invested largely on promotions but lacked in coherent campaigns as compared to IndiGo. In fact, IndiGo has also been looked at as a case study for effective integrated marketing communication practices in Kruti Shah's (2014) book 'Advertising and Integrated Marketing Communications'. She states that over time IndiGo has managed to break away from the tag of 'cheap' and 'low-cost' airlines to one that is 'no-frills chic'.

While IndiGo has come up with regular advertising campaigns time and again using different media, Go has not been very active as an advertiser. The campaigns launched by IndiGo have always been in line with their brand positioning. Their 2010 ad campaign with the central message being 'on time is a good thing' strengthened their position as the leading on time carrier in the four months preceding the campaign (Ghosal, 2010). In 2011, when IndiGo introduced its international flights, it did so with a musical television ad. As reported by Bhatt (2011, p. 4), "throughout the TVC the tempo of the script is maintained in a poetic rhythm characteristic of a Broadway play," connoting the smooth and hassle free services of IndiGo. 
The then president of Indigo, Aditya Ghosh commented, "Our all-new lively advertisement not only celebrates the milestone of us going international but also reiterates our promise of providing a hassle free and on time travel experience to our valued customers" (Bhatt, 2011, p. 5). Indigo has also been successful with target marketing with its 2015 outdoor campaign promoting same day return flights aimed at business travelers (Kotoky, 2015).

Go, on the other hand, has had very few widespread campaigns. The Go Air challenge in 2006 was an aggressive marketing campaign to battle competition where it provided customers getting a better fare rate on competing airlines twice the difference in reimbursement (Madison PR, 2006). But that was a long time ago. Another campaign was in 2014 which used the outdoor medium. The campaign was "to reinforce its brand presence in the target markets" (Chhabra, 2014).

Table 3: Ratio of ticketing, sales and promotion expenditure over total operating revenues of case organizations for 2015-16

\begin{tabular}{|c|c|c|}
\hline Ratio of Ticketing, Sales \& Promotion & Indigo Airlines & Go Air \\
\cline { 2 - 3 } $\begin{array}{c}\text { Expenditure over Total Operating Revenues } \\
\text { for 2015-16 (INR }{ }^{1} \text { ) }\end{array}$ & $6 \%$ & $3 \%$ \\
\hline
\end{tabular}

Further, as seen in table 3, Indigo relatively spends more in percentage terms on ticketing, sales and promotions. This does help in getting noticed by consumers and prospects.

The advertising efforts of both the airlines were examined by the experts. This was based on message strategy and media strategy as suggested by Kotler and Keller (2009). The experts noted that there was no widespread use of diverse media in both the cases. They gave a rating of "Good" and "Average" to Indigo and Go respectively.

\subsubsection{External Brand Communications}

The efforts of the case organizations in generating positive external brand communications are discussed in this section. This is divided into the following sub-sections.

\subsubsection{Corporate Awards}

Indigo lays special emphasis on participating in different forums and events pertaining to the aviation industry. This, aided by its superior service, has helped it to win many corporate

${ }^{1}$ INR stands for Indian Rupee 
awards. The awards won by IndiGo Airlines in last 3 years are listed below (IndiGo, 2015a, p. 1).

- $\quad$ "Most outstanding domestic airline at Travel and Hospitality Award 2014, New Delhi, January 2015

- $\quad$ Most preferred domestic airline of the year at North East Consumer Awards 2014, Guwahati, January 2015

- $\quad$ Best domestic airline at East India Travel Awards, Kolkata, October 2014

- $\quad$ Most Valuable Brand 2014 in Aviation \& Logistics by WCRC 100 Most Valuable brands of the year, Mumbai, December 2014

- $\quad$ Favourite Domestic Airline by Conde Nast Traveller at the Reader's Travel Award 2014

- $\quad$ Best Indian Airline at 7th International Conference on Indian Civil Aviation, ASSOCHAM, Oct 14, Delhi

- $\quad$ The Porter Prize for Industry Architectural Shift by Institute of Competitiveness, Delhi, September 2014

- $\quad$ Customer Value Leadership Award at The Global Community of Growth, Innovation and Leadership conference by Frost \& Sullivan, Mumbai, September 2014

- $\quad$ Best Domestic Airline at the 3rd Annual GMR IGI Airport Awards, Gurgaon, July 2014

- $\quad$ Best Domestic Airline by Trav Talk at India Travel Awards - West, Pune, July 2014

- $\quad$ Outstanding Excellence in Customer service at ET Customer Experience Management Summit, July 2014

- Best Low-Cost Airline in Central Asia and India at the Skytrax World Airline Awards, Farnborough UK, June 2014,

- $\quad$ Best Domestic Airline at CNBC Travel Awards, Indore, June 2014

- $\quad$ Award for Airline of the year (domestic) and fastest growing airline at inaugural BIAL Pinnacle Awards, Bengaluru, May 2014

- $\quad$ Outstanding Travel Experience at ASSOCHAM Think Tourism Think India Thought Leadership Meet, New Delhi, March 2014

- $\quad$ Best Airline-India at the Travel Leisure awards, New Delhi, March 2014

- $\quad$ Award for Excellence in Airline and Excellence in In-flight Services in LCC category at Aviation awards by SAP Media Worldwide Ltd, Hyderabad, March 2014"

As far as Go Air is concerned, the airline has managed to win only one award in the last three years (GoAir, 2014). This was the "Cargo Airline of the Year 2014 Award", which is not very relevant to its passenger business. Winning performance excellence awards can lead to a lot 
of free media coverage and positive consumer conversations around the brand. Based on the above information, the experts rated Indigo as "Very Good" and Go as "Poor".

\subsubsection{CSR Activities}

IndiGo has a dedicated CSR programme, IndiGoReach, which is aimed at reaching out to the less privileged sections of the society and works for their betterment (IndiGo, 2015b). The key focus areas that IndiGoReach works for include the environment, children and women. In association with Make a Wish Foundation, IndiGoReach enables children with life threatening diseases to fulfill their desires. With the help of their employees, IndiGo runs programs to spread awareness amongst children regarding hygiene and substance abuse. To promote education and literacy, IndiGoReach contributes to schools like 'Tamana' in the form of cupboards for classrooms and stationary for children.

For the environment, IndiGo is committed to reduce carbon emissions by sponsoring rural populations at certain places with environmental friendly options of energy production like biogas plants, solar cookers and heaters and so on. IndiGo is the first Indian airlines to associate with Fair Climate Network for low carbon rural development. IndiGo planted 655 silver oak trees near Bengaluru airport in the year 2014 keeping in mind that trees play a crucial role in maintaining ecological balance. Roping in their employees, IndiGo has conducted cycle rallies and celebrated the world ozone day on a large scale to generate awareness for the environment.

Empowering women has been a priority agenda for IndiGo airlines. As compared to the world average of $14 \%$, IndiGo airlines have $20 \%$ females in their executive positions. Approximately $40 \%$ of IndiGo workforce is female. Apart from the environment, children and women, IndiGoReach makes sure to provide support in times of natural calamities like in the case of the Uttarakhand floods in 2013.

Go Air, on the other hand, has a CSR policy document in place but no annual reports have been made public yet. The policy document states that Go Air will collaborate with NGOs and other social service organizations in order to encourage programmes in different parts of the country (GoAir, 2015). There is no structure given as to the key areas of development or empowerment and the CSR document primarily conforms to the guidelines laid down by the government. Internet search did not yield any information about their CSR activities. Based on the above information, the experts rated Indigo as "Good" and Go as "Poor". 


\subsubsection{Social Media Activities}

Social media activities done by a brand can lead to a lot of consumer conversations. Amongst the various social media platforms available today, Indigo and Go have active presence only on Facebook, the most popular of the lot. Therefore, only the activities of the both the airlines on Facebook was examined.

On its Facebook page, IndiGo has a mix of its ads and updates on its flight schedules and weather conditions of different cities. Go has uploads only limited to its advertising and other marketing efforts. Both the airlines are responsive to comments made on various posts by their customers. However, based on the frequency of response time, Facebook has labeled the IndiGo page as one that 'typically replies within an hour' whereas the Go Air page is labeled as one that 'typically replies within a few hours'. The official page of IndiGo has 464,755 likes whereas Go Air is far behind at 129,652 (as of $17^{\text {th }}$ July, 2016).

Based on the above information, the experts rated Indigo as "Average" and Go as "Below Average".

\subsubsection{Customers' Experience With the Brand}

In this section, the efforts of the airlines with respect to enhancing the customer's experience with the brand are being discussed. This section comprises three sub-sections, which are discussed as follows.

\subsubsection{Employee Care}

Here, the details of salaries and work load of employees of both the airlines are discussed. Good employee care does impact a service organization's revenue growth and profitability (Heskett, Jones, Loveman, Sasser, \& Schlesinger, 1994).

The following table shows a comparison of average salaries of both the airlines fetched from the website of Directorate General of Civil Aviation (DGCA, 2016). As can be seen, Indigo paid significantly higher remuneration (compared to Go) to its staff in 2015-16. Particularly, Indigo pays significantly higher salaries to front end employees, who interact directly with consumers and that way, influence their overall travel experience. Data was also fetched from the regulator's website regarding number of cabin crew as well as ground staff per aircraft in the case of both the airlines. They are displayed in Table 5. 
A higher number of front end employees per aircraft aids in better customer care. As seen in Table 8, Indigo, by providing more frontline employees per aircraft, ensures better customer experience. Based on the above information, the experts rated Indigo as "Good" and Go as "Average".

Table 4: Personnel salaries of case organizations for 2015-16

\begin{tabular}{|c|c|c|c|}
\hline \multirow[b]{2}{*}{ Category of staff } & Indigo Airlines & Go Air & \multirow{2}{*}{$\begin{array}{l}\text { \% Difference in } \\
\text { Avg. Salaries of } \\
\text { Indigo vs. Go }\end{array}$} \\
\hline & $\begin{array}{l}\text { Avg. Salaries } \\
\quad\left(\text { INR }^{2}\right)\end{array}$ & $\begin{array}{l}\text { Avg. Salaries } \\
\text { (INR) }\end{array}$ & \\
\hline Pilots and co-pilots & $5,665,152$ & $5,562,870$ & $2 \%$ \\
\hline Other cockpit personnel & $2,850,000$ & 791549 & $260 \%$ \\
\hline Cabin attendants & 508,730 & 400,024 & $27 \%$ \\
\hline $\begin{array}{l}\text { Maintenance and overhaul } \\
\text { personnel }\end{array}$ & $1,092,016$ & 915,044 & $19 \%$ \\
\hline Ticketing and sales personnel & $1,231,884$ & 391,058 & $215 \%$ \\
\hline
\end{tabular}

Table 5: Number of frontline employees per aircraft of case organizations for $2015-16$

\begin{tabular}{|c|c|c|}
\hline Parameter & Indigo Airlines & Go Air \\
\hline Nos. of cabin and support crew per aircraft & 27 & 22 \\
\hline Nos. of ground staff per aircraft & 61 & 21 \\
\hline
\end{tabular}

\subsubsection{Operations Design}

Further, Indigo provides more convenience to its flyers compared to Go due to larger fleet size, more number of flights and routes, as displayed in the table below.

Table 6: Operational details of case organizations for 2015-16

\begin{tabular}{|l|c|c|}
\hline Parameter & Indigo Airlines (IndiGo, 2016b) & Go Air (Chowdhury, 2016) \\
\hline Nos. of aircraft & 108 & 20 \\
\hline Nos. of flights & 806 & 141 \\
\hline Nos. of destinations & 40 & 22 \\
\hline
\end{tabular}

\footnotetext{
21 INR $=0.015$ USD; 1 INR $=0.014$ EUR $(1$ USD $=66.235$ INR; 1 EUR $=71.921)$ as on $1^{\text {st }}$ January, 2016
} 
The difference between Indigo and Go is very stark. The experts rated Indigo as "Very Good" and Go as "Poor".

\subsubsection{Brand Promise Delivery}

Data fetched from the regulator and displayed in the following table shows the performance of Indigo and Go on relevant operational parameters. Clearly, Indigo lives by its brand promise.

Table 7: Customer complaints and other operational data for $2015-16$ for case organizations

\begin{tabular}{|c|c|c|}
\hline Parameter & Indigo Airlines & Go Air \\
\hline Nos. of complaints/ 10,000 PAX & 0.30 & 1.20 \\
\hline Flight cancellations & $0.79 \%$ & $0.36 \%$ \\
\hline On-time Performance (for four metro airports) & $81.2 \%$ & $70.9 \%$ \\
\hline
\end{tabular}

The in-flight announcement script of Indigo is accentuated by words like "on-time" and "before-time", which reinforce their positioning. On the other hand, the Go script does not any make reference to their positioning of "smart people's flyer".

The on-ground as well as in-flight announcement scripts are more courteous in case of Indigo versus Go. As a proof, the Indigo announcement script uses the word "guests" instead of "passengers" in case of Go.

About.com is a website where experts share their views on topics of diverse nature. Tagged as India's travel expert, Sharell Cook (2015) has reviewed both IndiGo and Go Air in her article 'Guide to Domestic Airlines in India'. For IndiGo, she states that "the airline hasn't compromised on punctuality, connectivity of flights, safety, or customer service. If you're looking to fly with a low cost airline, IndiGo offers excellent "value for money". In her review of Go Air, she states that it has often been subjected to complaints for punctuality which the airline is trying to tackle in the best possible manner. Here again, the experts rated Indigo as "Very Good" and Go as "Average".

\subsubsection{Embedded Case: Consumer Survey}

The consumer survey comprised two parts viz. computation of NPS and service performance perception (SERVPERF) study. Computing NPS involved asking respondents one single question using a $0-10$ scale (where 0 is least likely and 10 is most likely): would you 
recommend this company to your friends and acquaintances? Further, the respondents were administered the SERVPERF scale developed by Parasuraman, Zeithaml, and Berry (1988). This scale measures the service performance perceptions of consumers. Compared to SERVQUAL scale, the SERVPERF scale is respondent-friendly and is a better indicator of overall service quality of a firm (Jain \& Gupta, 2004). Since sampling used is non-random, inferential statistics such as ANOVA will not be applicable and hence not used for analysis (Malhotra \& Dash, 2011). More details are provided in the following sub-sections.

\subsection{Net Promoter Score}

NPS is computed by subtracting the percentage of customers who have given 9 or 10 ratings (called promoters) minus those who have given 0 to 6 ratings (called detractors) (Reichheld, 2003). Passively satisfied customers are those who have given 7 or 8 rating in the survey.

Table 8: Net Promoter Scores (NPS) of case organizations

\begin{tabular}{|c|c|c|}
\hline Parameter & Indigo Airlines & Go Air \\
\hline$\%$ Detractors & $10 \%$ & $75 \%$ \\
\hline$\%$ Passively Satisfied Customers & $28 \%$ & $21 \%$ \\
\hline$\%$ Promoters & $62 \%$ & $4 \%$ \\
\hline NPS & $52 \%$ & $-71 \%$ \\
\hline
\end{tabular}

Clearly, Indigo is miles ahead compared to Go. This is because of high percentage of promoters and low percentage of detractors. However, the percentage of passively satisfied customers is significant even in the case of Indigo. This suggests that Indigo has to find out ways to improve the customer experience. This will help in boosting the present NPS to more than $75 \%$ - a level at which Amazon and other highly customer focused service organizations operate (Reichheld, 2003).

While, Go Air has to do serious conversations with its customers to identify the reasons for high dissatisfaction (75\% detractors). Further, it has to make concerted efforts and work on eliminating the factors causing high dissatisfaction. Based on the above information, the experts rated Indigo as "Very Good" and Go as "Very Poor".

\subsection{Service Performance Perceptions}

The survey findings revealed that the consumer perceptions of service quality are higher (by as much as $20 \%$ ) in case of Indigo versus Go. 
Table 9: SERVPERF results of case organizations

\begin{tabular}{|l|c|c|c|c|}
\hline \multicolumn{5}{|c|}{ SERVPERF Results } \\
\hline Dimensions & Mean & Standard Deviation & Mean & Standard Deviation \\
\hline & \multicolumn{3}{|c|}{ Indigo Airlines } & \multicolumn{2}{c|}{ Go Air } \\
\hline Reliability & 4.01 & 0.81 & 3.03 & 0.72 \\
\hline Responsiveness & 3.88 & 0.80 & 3.11 & 0.70 \\
\hline Assurance & 3.85 & 0.81 & 3.09 & 0.74 \\
\hline Empathy & 3.14 & 0.83 & 2.84 & 0.78 \\
\hline Tangibles & 3.78 & 0.88 & 3.24 & 0.78 \\
\hline
\end{tabular}

As seen in table 9, the maximum difference between the perceptions of Indigo and Go are on reliability followed by assurance, responsiveness, tangibles, and empathy. Empathy is an area where consumer perceptions of both Indigo and Go are low. This time, the experts rated Indigo as "Almost Good" and Go as "Below Average".

\subsection{Sample Descriptive Statistics}

The descriptive statistics of the sample are presented in tables $10,11,12$ and 13 . As shown in the tables, the sample chosen on basis of convenience was quite balanced in terms of gender. All the respondents belonged to Generation $Y$ with $46 \%$ respondents coming from 18-25 years age group and rest from 26-30 years age group. In terms of occupation, executives are the largest category (54.36\%) followed by students (25.36\%) and selfemployed professionals (20\%). On annual household income, the INR $1.0-1.9$ million (mn) income category was the largest distantly followed by the INR $2.0 \mathrm{mn} \&$ above category and thereafter, the INR $0.5-0.9 \mathrm{mn}$ category.

Table 10: Sample descriptive statistics- Gender

\begin{tabular}{|c|c|c|}
\hline \multicolumn{3}{|c|}{ Descriptive Statistics: Gender } \\
\hline Male & 201 & $51.54 \%$ \\
\hline Female & 189 & $48.46 \%$ \\
\hline Total & $\mathbf{3 9 0}$ & $\mathbf{1 0 0 . 0 0 \%}$ \\
\hline
\end{tabular}


Table 11: Sample descriptive statistics - Age Group

\begin{tabular}{|c|c|c|}
\hline \multicolumn{3}{|c|}{ Descriptive Statistics: Age Group } \\
\hline $18-25$ & 180 & $46.15 \%$ \\
\hline $26-30$ & 210 & $53.85 \%$ \\
\hline Total & $\mathbf{3 9 0}$ & $\mathbf{1 0 0 . 0 0} \%$ \\
\hline
\end{tabular}

Table 12: Sample descriptive statistics - Occupation

\begin{tabular}{|c|c|c|}
\hline \multicolumn{3}{|c|}{ Descriptive Statistics: Occupation } \\
\hline Students & 100 & $25.64 \%$ \\
\hline Executives & 212 & $54.36 \%$ \\
\hline Self-Employed & 78 & $20.00 \%$ \\
\hline Total & $\mathbf{3 9 0}$ & $\mathbf{1 0 0 . 0 0 \%}$ \\
\hline
\end{tabular}

Table 13: Sample descriptive statistics - Annual household income

\begin{tabular}{|c|c|c|}
\hline \multicolumn{2}{|c|}{ Descriptive Statistics: Annual Household Income (INR) } \\
\hline$<0.5 \mathrm{mn}$ & 0 & $0.00 \%$ \\
\hline $0.5-0.9 \mathrm{mn}$ & 38 & $9.74 \%$ \\
\hline $1.0-1.9 \mathrm{mn}$ & 286 & $73.33 \%$ \\
\hline $2.0 \mathrm{mn} \&$ Above & 66 & $16.92 \%$ \\
\hline Total & $\mathbf{3 9 0}$ & $\mathbf{1 0 0 . 0 0} \%$ \\
\hline
\end{tabular}

\section{SUMMARY AND CONCLUSIONS}

Table 14 presents the cross-case analysis summary in response to the secondary research questions of the present study. Finally, to address the larger research question (What are the driving factors for building brand equity in the context of airline services?), factors wherein, the case organizations diverge significantly in terms of their efforts, were identified. As mentioned earlier, both the case organizations are at opposite ends of the revenue/ market share spectrum. Therefore, the factors wherein the organizational efforts diverge would be the driving factors. They are shown in italics (e.g., $1 C, 2 A, 2 B, 3 A, 3 B, 3 C$ ) in table 14. 
Table 14: Cross-case analysis summary

\begin{tabular}{|c|c|c|c|}
\hline S. No. & Particulars & Indigo Airlines & Go Air \\
\hline 1 & \multicolumn{3}{|c|}{ Company's Presented Brand } \\
\hline $1 \mathrm{~A}$ & Brand Elements & Good & Good \\
\hline 1B & Brand Positioning & Good & Good \\
\hline $1 C$ & Advertising & Good & Average \\
\hline 2 & \multicolumn{3}{|c|}{ External Brand Communications } \\
\hline $2 A$ & Corporate Awards & Very Good & Poor \\
\hline $2 B$ & CSR Activities & Good & Poor \\
\hline $2 C$ & Social Media Activities & Average & Below Average \\
\hline 3 & \multicolumn{3}{|c|}{ Customer's Experience with the Company } \\
\hline $3 A$ & Employee Care & Good & Average \\
\hline $3 B$ & Operations Design & Very Good & Poor \\
\hline \multirow[t]{2}{*}{$3 C$} & Brand Promise Delivery & Very Good & Average \\
\hline & Consumer Evaluations & & \\
\hline $\mathrm{i}$ & NPS & Very Good & Very Poor \\
\hline ii & Service Performance Perceptions & Almost Good & Below Average \\
\hline
\end{tabular}

Further, the performance of both the organizations on the first component, company's presented brand, is more or less similar. Therefore, the major drivers for contrasting outcomes cannot come from this. This is very much in alignment with the results of the empirical study done by Fung So and King (2010).

Additionally, of all the three components, Indigo performs best in the third component, customer's experience with the company. According to Berry (2000), this is the dominant contributor to brand equity. The consumer evaluations, though not generalizable, are clearly in favour of Indigo, especially, in the case of Net Promoter Score (NPS). Finally, Indigo does reasonably well in the second component, external brand communications. Whereas, Go is comparatively far behind in the second and third components.

The above discussion is captured in a unique conceptual framework inductively developed by the authors and displayed in figure 3. Customer's experience with the company is most crucial 
to brand equity formation. This is manifested in the following factors viz. Employee care, operations design, and brand promise delivery. It is evident from the factors that, collectively, they are very resource intensive. The next factor in terms of importance is external brand communications. This comprises corporate awards, CSR activities, and social media activities. This factor should be moderately resource intensive to be in tandem with the importance of the factor. Finally, company's presented brand is least important in terms of its impact on brand building. Therefore, resource requirements/ allocation for this factor should be least as well.

Figure 3: Brand building in airlines: A conceptual framework

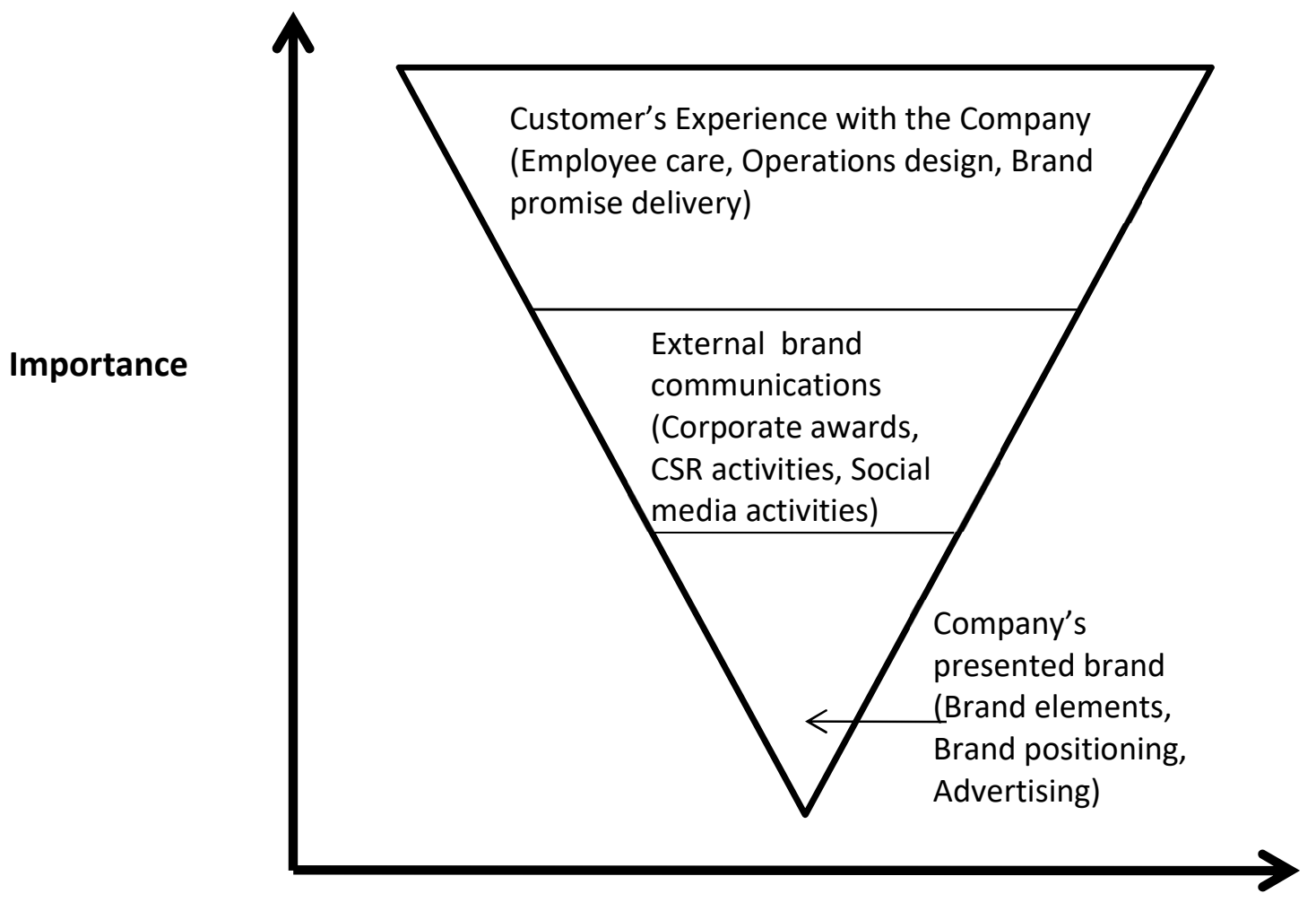

Resource Requirements

\section{IMPLICATIONS FOR RESEARCH AND PRACTICE}

There is enough literature to suggest that qualitative studies using case study research can be conclusive (e.g., Flyvberg, 2006; Yin, 2009, etc). Therefore, the findings of this study should be taken seriously by practitioners. However, in the present study, depth interview (DI) was largely avoided due to major difficulties experienced in accessing airline officials. Use of DIs would have added more depth to the present study and interested researchers can look into same while replicating this study. Also, future researchers can choose to empirically test the proposed conceptual framework to check its applicability across different contexts. 
As regards practitioners, the framework gives clear pointers about how to go about building strong brand equity. Branding is not just the work of brand managers; rather, it encompasses multiple functions. The present paper, based on empirical research, inverts the traditional pyramid for brand building, wherein advertising reigned supreme. Rather, customer's experience with the company should be the primary driver supported by external brand communications and company's presented brand.

Thus, the proposed conceptual model flips the current thinking of branding and provides a fresh and valuable perspective. It is hoped that airlines, across markets, will leverage these learnings to build stronger brand equity leading to higher customer loyalty, revenues and profits.

\section{REFERENCES}

1. Aaker, D. (1991). Managing Brand Equity. New York, NY: The Free Press.

2. afaqs. (2015, May 12). Airlines advertise heavily on radio: TAMAdEx. Retrieved July 22, 2016, from Afaqs: http://www.afaqs.com/news/story/44179_Airlines-advertise-heavilyon-radio-TAMAdEx

3. Aziz, N. A., \& Yasin, N. M. (2010). Analyzing the brand equity and resonance of banking services: Malaysian consumer perspective. International Journal of Marketing Studies , 2 (2), 180-189.

4. Baldauf, A., \& Cravens, K. B. (2003). Performance consequences of brand equity management; Evidence from organizations in the value chain. Journal of Product \& Brand Management, 220-236.

5. Berry, L. L. (2000). Cultivating service brand equity. Academy of Marketing Science , 28 (1), 128-137.

6. Bhatt, S. (2011, November 21). Indigo Airlines announces international service with a musical. Retrieved April 29, 2016, from CampaignIndia: http://www.campaignindia.in/Video/280815, indigo-airlines-announces-internationalservice-with-a-musical.aspx

7. Bick, N. (2009). Increasing shareholder value through building customer and brand equity. Journal of Marketing Management, 117-141.

8. Cardozo, J. (2014, September 25). Go Air goes outdoor to reinforce market presence. Retrieved July 22, 2016, from Media4Growth: http://www.media4growth.com/ooh/campaign-detail.html?id=285

9. Cennamo, L., \& Gardner, P. (2008). Generational differences in work values, outcomes and person-organizational values. Journal of Managerial Psychology , 891-904.

10. Chang, H. H., Hsu, C.-H., \& Chung, S. H. (2008). The antecedents and consequences of brand equity in service markets. Asia Pacific Management Review , 13 (3), 601-624.

11. Charlene, D. J. (2007). A conceptual view of branding for services. Innovative Marketing, $3(1), 7-14$. 
12. Chen, C.-F., \& Chang, Y.-Y. (2008). Airline brand equity, brand preference, and purchase intentions-The moderating effects of switching costs. Journal of Air Transport Management, 40-42.

13. Chen, C.-F., \& Tseng, W.-S. (2010). Exploring customer-based airline brand equity: Evidence from Taiwan. Transportation Journal, 49 (1), 24-34.

14. Chhabra, A. (2014, September 16). GoAir - taking flight on OOH wings. Retrieved April 29, 2016, from allaboutoutdoor: http://www.allaboutoutdoor.com/newsdetail.php?mid=3907\&keyword=\%20Commercial\%20Hubs

15. Chowdhury, A. (2016, August 23). 100 planes by 2023, finally, GoAir spreads its wings to take on rivals. Retrieved December 16, 2016, from The Economic Times: http://economictimes.indiatimes.com/industry/transportation/airlines-/-aviation/100planes-by-2023-finally-goair-spreads-its-wings-to-take-onrivals/articleshow/53819351.cms

16. Cobb-Walgren, C., Ruble, C., \& Donthu, N. (1995). Brand equity, brand preference, and purchase intent. Journal of Advertising , 25-40.

17. Cook, S. (2015, August 15). Guide to Domestic Airlines in India. Retrieved July 28, 2016, from goindia.about: http://goindia.about.com/od/air/tp/india-domestic-airlines.htm

18. de Charnatony, L., \& McDonald, M. (1998). Creating Powerful Brands in Customer, Service and Industrial Markets. Woburn: Butterworth-Heinemann.

19. de Torcy, G., Taylor, A., Delhaye, D., Schickel, Y., \& Fulcher, T. (2005, March). Customer lifetime value strategies in the financial services industry: Measures, implementations and practical impact. Cincom Financial Services Strategic Research , pp. 31-41.

20. DGCA. (2016). Directorate General of Civil Aviation. Retrieved January 6, 2017, from DGCA: http://dgca.nic.in/

21. Dibb, S., \& Simkin, L. (1993). The strength of branding and positioning in services. International Journal of Service Industry Management , 4(1), 25.

22. Flyvberg, B. (2006). Five misunderstandings about case-study research. Qualitative Inquiry, 219-245.

23. Fung So, K., \& King, C. (2010). "When experience matters": building and measuring hotel brand equity. International Journal of Contemporary Hospitality Management, 589-608.

24. Ghosal, A. (2010, May 21). On the dot with IndiGo. Retrieved April 29, 2016, from afaqs: http://www.afaqs.com/news/story/27140_On-the-dot-with-IndiGo

25. Ghosh, M. (2016, April 28). Indigo and SpiceJet domestic market share goes up: Report. Retrieved April 28, 2016, from The Financial Express: http://www.financialexpress.com/article/industry/companies/indigo-and-spicejetdomestic-market-share-goes-up-report/244329/

26. GoAir. (2016). About Us. Retrieved December 16, 2016, from Go Air: https://www.goair.in/menu/about-us

27. GoAir. (2015). Corporate Social Responsibility. Retrieved August 27, 2016, from Goair: https://www.goair.in/upload/PDF/co_go/Corporate\%20Social\%20Responsibility\%20Polic y.pdf

28. GoAir. (2014). Press release 25th June, 2014. Retrieved July 17, 2016, from Go Air: https://www.goair.in/bottom-menu/media-cen/press-release-25th-june-2014

29. Herriott, R., \& Firestone, W. (1983). Multisite qualitative policy research: Optimizing description and generalizability. Educational Researcher, 14-19. 
30. Heskett, J. L., Jones, T. O., Loveman, G. W., Sasser, W. E., \& Schlesinger, L. A. (1994). Putting the service-profit chain to work. Harvard Business Review, 164-174.

31. IndiGo . (2016b, June 1). IndiGo . Retrieved December 1, 2016, from Indigo Airlines: https://www.goindigo.in/content/dam/goindigo/investor-relations/press-releases/2016-

17/160601_IndiGo\%20enhances\%20connectivity\%20across\%20its\%20network\%20with \%2030\%20new\%20flts.pdf

32. IndiGo. (2016a, March). About IndiGo. Retrieved April 28, 2016, from IndiGo: https://content.goindigo.in/Corporate/About

33. IndiGo. (2015a). Awards. Retrieved July 16, 2016, from content.goindigo.in: https://content.goindigo.in/Information/Awards

34. IndiGo. (2015b). IndiGo CSR Report 2013-14. Retrieved August 28, 2016, from Goindigo.in: $\quad$ https://www.goindigo.in/content/dam/goindigo/6ewebsite/pdf/download/CSR_Report_13_14.pdf

35. Jain, S., \& Gupta, G. (2004). Measuring service quality: SERVQUAL vs. SERVPERF scales. Vikalpa , 25-37.

36. Kapferer, J. (2004). The New Strategic Brand Management. London: Kogan Page.

37. Kee Mun, W., \& Ghazali, M. (2011). Branding satisfaction in the airline industry: A comparative study of Malaysia Airlines and Air Asia. African Journal of Business Management, 5(8), 3410-3423.

38. Keller, K. (1998). Building, Measuring, and Managing Brand Equity. Englewood Cliffs, NJ: Prentice-Hall.

39. Keller, K. (1993). Conceptualizing, measuring, and managing customer-based brand equity. Journal of Marketing , 57(1), 1-22.

40. Kim, H., Kim, W., \& An, J. (2003). The effect of customer-based brand equity on firms' financial performance. Journal of Customer Marketing , 335-351.

41. Kitchen, P. J., \& Burgmann, I. (2010). Integrated Marketing Communication(Vol. 4). Wiley International Encyclopedia of Marketing.

42. Kotler, P. (1991). Marketing management: Analysis, planning and control(8th Edition ed.). Prentice Hall: Englewood Cliff.

43. Kotler, P., \& Keller, K. (2009). Marketing management. Upper Saddle River, N.J.: Pearson Prentice Hall.

44. Kotoky, A. (2015, July 30). IndiGo delivers on 'sleep with your wife' pitch ahead of IPO. Retrieved July 22, 2016, from Livemint: http://www.livemint.com/Companies/PQzZoLQg5g4AWw3JQnIAfL/IndiGo-delivers-onsleep-with-your-wife-pitch-ahead-of-IPO.html

45. Kotoky, A. (2015, July 30). IndiGo delivers on 'sleep with your wife' pitch ahead of IPO. Retrieved April 29, 2016, from LiveMint: http://www.livemint.com/Companies/PQzZoLQg5g4AWw3JQnIAfL/IndiGo-delivers-onsleep-with-your-wife-pitch-ahead-of-IPO.html

46. Kulshrestha, A., \& Chaturvedi, A. (2016, September 10). Hospitality sector sees boom in occupancy on rising tourist arrivals. The Economic Times , p. 6.

47. Lovelock, C., \& Wirtz, J. (2007). Services Marketing: People, Technology, Strategy (4th edition ed.). New Delhi: Pearson Prentice Hall.

48. Madison PR. (2006, March 7). GoAir challenges competition through marketing campaign. Retrieved April 29, 2016, from Moneycontrol: 
http://m.moneycontrol.com/news/business/goair-challenges-competition-throughmarketing-campaign_205217.html?page=1

49. Malhotra, N., \& Dash, S. (2011). Marketing Research: An Applied Orientation. New Delhi: Pearson.

50. Moorthi, Y. L. (2002). An approach to branding services. The Journal of Services Marketing, $16(2), 259-274$.

51. Neogy, S. (2015, September 7). The Dos and Don'ts of Selfie Promotions: Are brands being selfie-smart? - See more at: http://www.exchange4media.com/digital/the-dos-anddonts-of-selfie-promotionsare-brands-being-selfie-

smart_61533.htm/\#sthash.W62kIIKl.dpuf. Retrieved July 22, 2016, from Exchange4Media: http://www.exchange4media.com/digital/the-dos-and-donts-of-selfiepromotionsare-brands-being-selfie-smart_61533.html

52. Parasuraman, A., Zeithaml, V., \& Berry, L. (1988). SERVQUAL: A multiple-item scale measuring consumer perceptions of service quality. Journal of Retailing , 12-40.

53. Phadnis, A. (2015, June 27). GoAir's big test begins from 2016. Retrieved April 29, 2016, from business-standard: http://www.business-standard.com/article/companies/goair-sbig-test-begins-from-2016-115062600217_1.html

54. Reichheld, F. (2003). The one number you need to grow. Harvard Business Revew , 4654.

55. Ries, A., \& Trout, J. (2001). Positioning: The battle for your mind. New York: McGraw-Hill.

56. Rowley, J. (2002). Using case studies in research. Management Research Review, 16-26.

57. Shah, K. (2014). Advertising and integrated marketing communicatons. New Delhi: McGraw Hill Education Pvt. Ltd.

58. Shukla, T. (2016, February 19). New airlines more than double their market share. Retrieved April 28, 2016, from LiveMint: http://www.livemint.com/Companies/K1f9aLF5k7E06vvpYME1PN/New-airlines-morethan-double-their-market-share.html

59. Shultz, D. E. (1993). Integrated marketing communications: Maybe definition is in the point of view. Marketing News, $27(22)$.

60. Stahl, F., Heitmann, M., Lehmann, D., \& Neslin, S. (2012). The impact of brand equity on customer acquisition, retention, and profit margin. Journal of Marketing , 44-63.

61. Szmigin, I., \& O'Loughlin, D. (2007). Services branding: Revealing the rhetoric within retail banking. The Service Industries Journal , 27(4), 435-452.

62. Ugolini, M. M., Cassia, F., \& Vigolo, V. (2014). Services branding: Is it a matter of gender? The TQM Journal , $26(1), 75-87$.

63. Vargo, S., \& Lusch, R. (2004a). Evolving to a new dominant logic of marketing. Journal of Marketing , 1-17.

64. Vargo, S., \& Lusch, R. (2004b). The four services marketing myths: remnants from a manufacturing model. Journal of Service Research , 324-335.

65. Weingarten, R. (2009). Four generations, one workplace: A Gen X-Y staff nurse's view of team building in the emergency department. Journal of Emergency Nursing , 27-30.

66. Xiang, L., \& Petrick, J. (2008). Reexamining the dimensionality of brand loyalty: A case of the cruise industry. Journal of Travel \& Tourism Marketing , 25 (1), 68-85.

67. Yin, R. (2009). Case study research: Design and methods. Thousand Oaks, CA: Sage. 